\title{
Workers Who Produce Industrial Fabrics and Cultivate the Land: Textile Labor, Migrations and Connections between Rural and Factory Work
}

\author{
JuÇARA DA Silva Barbosa DE MELlO \\ Pontifícia Universidade Católica do Rio de Janeiro, Brasil \\ jsbmello@puc-rio.br \\ Felipe Augusto dos Santos Ribeiro \\ Universidade Estadual do Piauí, Brasil \\ feliperibeiro@phb.uespi.br
}

\begin{abstract}
This article explores the experiences of migrant workers, many from rural areas, who settled in a major center of the textile industry in Brazil, located in the state of Rio de Janeiro and which housed to four factories. Articulating several historical sources, we seek to understand both the agricultural practices maintained by migrants from the countryside, and the incentives to work in the fields fostered by employers in the factories. In contrast to studies guided by notions of modernization which have crudely linked the manufacturing world to progress as opposed to the agricultural, this article examines how rural and factory labor coexisted in multiple combinations. We argue that the term "roçado operário" (factory worker's farm), used in many studies, is not enough to describe a far more varied and complex social phenomenon. Therefore, we propose a new framework for understanding the various forms of land use by these workers.
\end{abstract}

Keywords: textile workers, migration, rural and factory work, weaving identities

Received: 30 March 2020. Approved: 7 July 2020. 


\section{Introduction}

(...) We worked in the countryside, planting corn, beans, potatoes... (...) It was very harsh there! We planted all day to get two thousand réis, to eat, drink and buy clothes... I worked with my father. I left home when I was eighteen and I've been here since 1942 (...). I arrived on July $28^{\text {th }}$. On the $29^{\text {th }}$ I started to work at the factory. I worked there for 33 years (...)- Licério

Ramos, 2013. ${ }^{1}$

The statement above shares themes that are recurrent in the recollections of Brazilian workers. Rural origin, migration, and factory work were formative in the lives of many men and women, workers like Licério Ramos, whose statements reveal identities marked by a common past. Licério was from Nova Friburgo, another city in the state of Rio de Janeiro, in the southeastern region of Brazil, where he worked in the countryside. In 1942, Licério went to a nearby town called Magé and found employment at the Santo Aleixo textile factory. Many other migrants followed similar paths. They arrived from all over Brazil in search of jobs in the textile industry, part of a migratory flow that accelerated after World War II.

The textile industry, which had already played an important role in South America since the beginning of the 2oth century, ended up acquiring greater prominence in this context of war, when expanded production generated by access to new foreign markets created unprecedented employment opportunities. Besides Brazil, there are quite interesting references about the impulse that the textile industry received during that period in "several other underdeveloped countries in Latin America”, particularly Argentina, Chile and Uruguay. ${ }^{2}$

1 Licério Ramos, 2013. Interview for documentary film “Tear” (Loom), [directed by Taiane Linhares], 2003, www.doctear.com.br (Mar. 31, 2014). The authors would like to thank university professors Bryan Pitts (UCLA International Institute) and Ruan Nunes Silva (Universidade Estadual do Piauí) for their decisive contributions in preliminary versions of this paper.

2 Stanley J. Stein, Origens e evolução da indústria têxtil no Brasil, 1850-1950 (Rio de Janeiro: Campus, 1979), 172. Original version: The Brazilian Cotton Manufacture: Textile Enterprise in an Underdeveloped Area, 1850-1950 (Cambridge: Harvard University Press, 1957). See also Peter Winn, Tejedores de la Revolución: los trabajadores de Tarur y la vía chilena al socialismo (Santiago: LOM Ediciones, 2004), 41; María Inés Fernández and Lilian Legnazzi, Mujeres en la industria textil: de la fábrica al taller clandestino (Buenos Aires: Biblos, 2012), 55; María Magdalena Camou and Silvana Maubrigades, "El desafío de la productividad en la industria 'tradicional' uruguaya”, in Trabajo e historia en el 
By demanding more industrial labor, men and women from all over the country, many from rural areas, sought work and forged new social relations, not only in textile factories, but in a wide variety of industries. Incidentally, this theme permeates much of academic research on Brazilian working classes. Studies in Social Sciences and Humanities proliferated after a series of sociological studies conducted in the 1950s and 1960s, inspired by the notion of modernization. Sociologist Juarez Brandão Lopes's pioneering 1957 case study of industrial relations in two communities of Minas Gerais's Zona da Mata region was representative of this aforementioned proliferation. Based on 350 interviews, mostly with textile workers, Brandão Lopes placed emphasis on the rural origin of the workers and their forms of organization and struggle. ${ }^{3}$ Brandão Lopes had as reference Stanley Stein, a historian whose classic study of the Brazilian textile industry emphasized the need for "modernization of the methods of administration" and who viewed it as "the biggest challenge posed to the Brazilian textile business owners" in the midtwentieth century. ${ }^{4}$ In light of Stein's contributions, Brandão Lopes sought to understand the worker's adjustment to this "new" industry, marked by the "destruction of the patrimonialist model of labor relations". As a result of these changes, he called the textile industry "the industry the most important obstacle to the traditional order in Brazil". ${ }^{5}$

However, it should be noted that the important contribution from Stein was an exception in Brazil for a few decades. This type of approach on labor relations was largely neglected by historians until the late 1970s, being more common in the field of sociology, then in anthropology and only later in history, mainly from the 1980 s and 90s on. Only in 2001 was a workgroup created in Brazil with the aim of expanding the discussion on labor in this light, "Worlds of Labor" - Brazilian History Association (GT "Mundos do Trabalho" - Associação Nacional de História - ANPUH), fruit of vigorous research on this theme in Brazil.

Although Brandão Lopes's work became a classic, his legacy, linked to a series of other studies from the 1950 s and 1960s, reinforced a structural division between the rural as synonymous with backwardness, and the urban

Uruguay: investigaciones recientes, coord. Camou and Rodolfo Porrini

(Montevideo: Universidad de la República, 2006), 84.

3 See Juarez Rubens Brandão Lopes, Sociedade industrial no Brasil (São Paulo:

Difel, 1964).

4. Stein, Origens e evolução, 184.

5 Brandão Lopes, Crise do Brasil arcaico (São Paulo: Difel, 1967), 1. 
as identical to progress. ${ }^{6}$ For example, scholars long took a pejorative approach to migrants from the Northeast of Brazil, even at times blaming them for the "lack" of class consciousness of Brazil's state-mediated, corporatist "old unionism" and its failure to mount resistance to the Brazil's civilian-military coup of 1964. In the academic field of history, several studies have sought to deconstruct these stereotypes, such as the research by Paulo Fontes. $^{7}$

Referring back to the quote at the beginning of this paper, Licério's own trajectory calls into question the dichotomies of old urban vs. rural and backwardness vs. progress because it shows that a "backwoods farmer" (roceiro) who went to work in the factory was also active in his union, in which he led strikes and rose to managerial positions. Licério's union was so politically active that in the wake of the 1964 coup the Ministry of Labor intervened to remove its president of the union, on charges of "communist subversion", just as the nickname "Little Moscow" was attributed to the city of Magé. "I was not a striker, but someone who demanded my own rights!" emphatically affirmed this former worker and union leader. ${ }^{9}$

But how can the story of the migrant Licério and so many other people and families who left rural areas to work in textile factories in the city of Magé (Rio de Janeiro, Brazil) really contribute to this discussion about workers who moved from the countryside to the city or from the land to the industrial work in factory?

First, it is necessary to problematize and question academic explanations that privilege the approach of the rural origin of the working class as a supposedly determining aspect to justify their "misconduct". Regrettably, this type of

6 It is important to emphasize that Brandão Lopes and similar works made important contributions to Brazilian sociology, especially through their pioneering use of case studies. The overemphasis on the notion of modernization that we criticize was reinforced less by the work of Brandão Lopes himself than by studies inspired by his work. See José Sérgio Leite Lopes, "Sobre os trabalhadores da grande indústria na pequena cidade: crítica e resgate da 'Crise do Brasil Arcaico"', in Cultura E̊ identidade operária: aspectos da cultura da classe trabalhadora, coord. Leite Lopes (Rio de Janeiro: Marco Zero; UFRJ, 1987), 147-170.

7 See Paulo Fontes, Um Nordeste em São Paulo: trabalhadores migrantes em São Miguel Paulista (1945-66) (Rio de Janeiro: Editora FGV, 2008). English version: Migration and the Making of Industrial São Paulo (Durham: Duke University Press, 2016).

8 See Felipe Ribeiro, Memórias da Moscouzinho: os tecelões de Santo Aleixo e a liderança de Astério dos Santos (Jundiaí: Paco Editorial, 2016).

$9 \quad$ Licério Ramos, 2013. 
argument is still very influential, resisting as a kind of analytical paradigm and still inspiring current works, even if in a veiled way, without due problematization. What's more, to make matters worse, the representations based on this crude dichotomy between the rural and the urban end up hiding, in academic studies, very relevant social phenomena. ${ }^{10}$

Besides that, we point out that this discussion finds itself amidst widespread debate in the global and international labor history, particularly in perspective of the global south. An important example is the Indian historiographical production dedicated to the study of textile workers, discussing the typical reports about the work space, in which the factory was considered a symbol that would celebrate the meeting of rural migrants with development, thus revealing the principles of modernity. We emphasize that this Indian historiographical trend has acquired notoriety, mainly through the work of Dipesh Chakrabarty, after research on workers in Bengal, a region located in the east of India. In his studies, the author highlighted the strong peasant heritage in the country, where the working class was formed mainly by rural migrants, who would have maintained a strong influence of their traditional culture in the industrial universe. However, this "transfer" of peasant culture to the city was fiercely contested by other researchers, such as Rajnarayan Chandavarkar and Samita Sen, on the grounds that ancient culture was also transformed throughout the historical process by work, politics and experience of these workers. In an article translated and published in Brazil, the Indian historian Chitra Joshi stated that the journey from the village to the city in India was normally described as a history of progress, as we have identified in part of the historiography concerning Brazil. In identifying that the nature of the connection between the village and the city was a recurrent theme in texts on labor in India, the author reiterated that human and material flows between the rural and urban world were important in building the bonds between the city and the countryside. Yet, he suggested that historical analysis has placed more value on the understanding of the dialectical relationship that workers maintain with the spaces they inhabit and work in, whether in the factory or in the fields. ${ }^{11}$

Incidentally, in the most recent debates on the labor history, the echoes of marxist analogy with the French peasants of the 19th century have also been pointed out as arguably responsible for the academic view that, directly or

10 Enzo Mingione and Enrico Pugliese, “A difícil delimitação do 'urbano’ e do 'rural': alguns exemplos e implicações teóricas”, Revista Crítica de Ciências Sociais, 22 (1987): 86.

11 See Chitra Joshi, "Espaços do trabalho e história social na Índia”, Estudos Históricos, 22 (2009): 05-30. 
indirectly, still denotes the rural sector as backward and the industrial setting as modern.

(...) Thus, even in few labor historians have dismissed agricultural workers with the condescension of Marx's "sack potatoes", as a collectivity we have paid them insufficient attention and our field is weaker as a result. (...) In short, we want to suggest that the countryside is a site where class "happens" and that an understanding of both the rural and urban sectors will be enhanced if we begin to study them both as coequals and as interdependent. ${ }^{12}$

Taking into consideration research centered on the city of Magé (Rio de Janeiro, Brazil), previously carried out by the co-authors of this article and having as historical basis the intense migration process around textile factories registered after the World War II, we consider the expression “factory worker's farm” (roçado operário in Portuguese) too restricted to refer to factory workers that cultivate the land in various ways, whether in their yard or in the surroundings of the factory. In view of this insufficiency, we propose new typologies to try to explain such complex experiences, in order to deepen a debate that we consider important to think about the relationship between the rural and urban dichotomy in the history of work.

By researching these historical processes, common to a variety of social actors, in dialogue with the field of labor anthropology, we offer a reflection on the construction of identities linked to "farm work". At the most fundamental level, two types of labor stand out. On the one hand, there was labor whose agricultural production was destined for the textile factory itself, usually to supply the market of foods in the workers' village. On the other hand, factories often encouraged agricultural work as a form of supplementary income or a way to fill textile families free time, without allowing the food to be sold. Most significantly, we offer a new perspective on a long-standing debate about the relationship between farm and factory work by showing that the "factory worker's farm" was a far more complex and multifaceted phenomenon than has been previously assumed. The coexistence of different kinds of work, in the fields and in the highly hierarchical environment of the factory, decisively shaped worker's identities, political stances, and relations with employers.

12 Cindy Hahamovitch and Rick Halpern, "Not a 'sack of potatoes': why labor historians need to take agriculture seriously”, International Labor and WorkingClass History, 65 (2004): 3-4. 


\section{Textile Industrialization in Magé}

With a very old colonial occupation, Magé came to occupy a prominent place in the agricultural production of food until the first half of the 19th century, when it supplied to the city of Rio de Janeiro, the then capital of Brazil. The city's first textile factories were founded in the middle of the 19th century, attracted mainly by the potential for water power of the rivers that descend from the nearby Serra dos Órgãos mountains. The factories entitled Santo Aleixo (founded in 1848), Pau Grande (1878), Andorinhas (1890) and Mageense (1891) would later turn the city of Magé into an important industrial center for cotton spinning and weaving. ${ }^{13}$

After World War I, the América Fabril company, owner of the Pau Grande factory and other facilities in the state of Rio de Janeiro, established itself as the most important textile company in the country, "with capital and production value much higher than those of any other company in Brazil". ${ }^{14}$ The rapid expansion of this company ensured its survival after the 1929 stock market crash, but the city's other textile factories were temporarily forced to close. ${ }^{15}$ They would soon be acquired by emerging textile conglomerates. Mageense was acquired in 1933-34 by the Santo Amaro company. Andorinhas was purchased by the Mattheis group in 1935, joining the Fábricas Unidas de Tecidos, Rendas e Bordados S/A, which boasted plants in Rio e Janeiro and in the inland municipality of Valença. Finally, in 1941, Santo Aleixo became part of the Companhia de Fiação e Tecelagem Bezzera de Mello, which also owned plants in the states of Pernambuco, Alagoas, and Minas Gerais.

13 See Juçara da Silva Barbosa de Mello, Identidade, memória e história em Santo Aleixo: aspectos do cotidiano operário na construção de uma cultura fabril (Curitiba: Prismas/Appris, 2019).

14 Elisabeth von der Weid and Ana Marta Rodrigues Bastos, O Fio da Meada: Estratégia e Expansão de uma indústria têxtil: Companhia América Fabril 1878/1930 (Rio de Janeiro: Fundação Casa de Rui Barbosa, 1986), 22.

15 Newspapers even reported that the textile workers of Magé would work in agriculture: "Something interesting to note is the absorption into agricultural labor of the workers who the textile factories' strike in Magé will leave without jobs." See Diário de Notícias (Dec. 13, 1930), 13. 


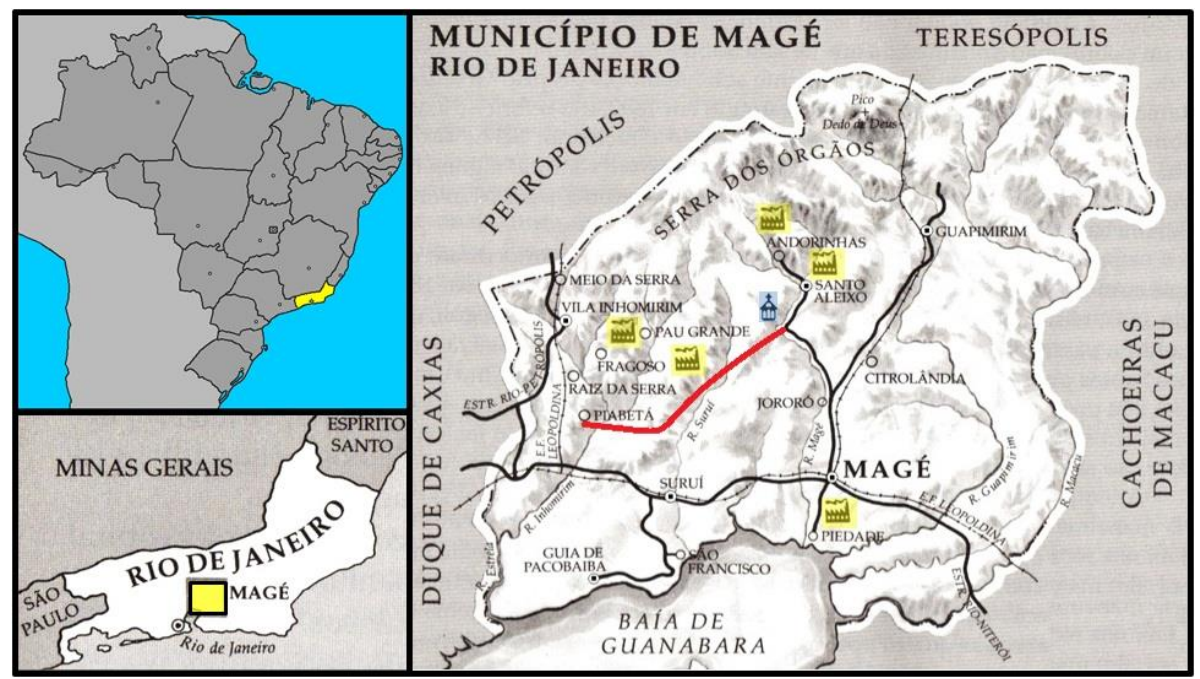

Figure 1: Map of the municipality of Magé with textile factories indicated (in yellow), the Chapel of Santo Aleixo (blue) and the approximate outline of the Santo Aleixo-Piabetá road (red). Source: Ruy Castro, Estrela Solitária: um brasileiro chamado Garrincha. Rio de Janeiro: Companhia das Letras, 1996. p.14. (Image adapted by the authors of this article).

All these companies, to greater or lesser degrees, invested in the lives of their workers beyond the factory, focusing primarily on the development of housing. ${ }^{16}$ As early as the 1890s, the Companhia América Fabril pioneered a "factory and workers' village." Andorinhas and Santo Aleixo created similar projects, but it was only in the 1930s that they would invest in workers' villages on a significant scale. ${ }^{17}$ The exception was Mageense factory

16 The main reference on this topic is the work of Leite Lopes, who argues that the factory-owned workers' villages were the product of the power of employers, "a situation in which the factory itself owns the houses in which its workers live and becomes involved in the community's social life outside the workplace." See Leite Lopes, A Tecelagem dos Conflitos de Classe na Cidade das Chaminés (Brasília: Editora UNB; Marco Zero, 1988), 17.

17 There are sources that indicate that as early as the mid-1 $19^{\text {th }}$ century the Santo Aleixo factory provided accommodations for its employees, housing women separately. This was necessitated by the fact that many employees were German immigrants from Petrópolis, located about $20 \mathrm{~km}$ away over mountainous terrain. See Geraldo de Beauclair Mendes de Oliveira, Raízes da indústria no Brasil: a pré-indústria fluminense, 1808-1860 (Rio de Janeiro: Studio F\&S Editora, 1992), 146-147. However, following Leite Lopes, we do not see this type of accommodation as fitting the model of a factory-owned workers' village. 
(formerly called Companhia Mageense), in the city center, which built singlefamily housing for workers, but not entire neighborhoods.

Company-built workers' villages are a recurrent theme across academic disciplines in research on industrialization and memory among the working class. Some of these studies mention workers' villages built by textile factories in Magé.

Textile establishments with worker housing characterized industrial development in the state of Rio de Janeiro. Examples include the 'Esther' and the 'Andorinhas' factories, in Santo Aleixo, and the 'Levy Gasparian' cotton mill, established in Três Rios. The 'Pau Grande' textile and weaving factory, founded in Magé in 1878, gave rise to an important industrial center-Pau Grande, which in the 1950s and 1960s gained fame as the place where [legendary Brazilian footballer] Mané Garrincha was born and began his career. The 'América Fabril' company owned many factories in the State of Rio de Janeiro, all providing homes for their workers. In addition to Pau Grande, it had other factories with housing. ${ }^{18}$

Starting in the 1940s, the government of Brazilian president Getúlio Vargas also constructed workers' villages for the factories of state-owned companies. An icon of this initiative was the Presidente Vargas plant of the National Steel Company (Companhia Siderúrgica Nacional - CSN), in Volta Redonda, State of Rio de Janeiro. ${ }^{19}$

The industrial neighborhoods of Magé have been called a "specific case that shows the possibilities suggested by the model of the factory-owned workers' village". ${ }^{20}$ These possibilities emerge through a case-by-case study of the municipality's assorted workers' villages, which in turn reveals connections

18 Philip Gunn and Telma de Barros Correia, "A industrialização brasileira e a dimensão geográfica dos estabelecimentos industriais”, Revista Brasileira de Estudos Urbanos e Regionais, 7 (2005): 29. The Esther factory mentioned in the quotation is the Santo Aleixo factory, renamed by the Bezerra de Mello company.

19 It should be noted that some authors point out conceptual distinctions between "factory-owned workers' village" and "company town," which still need to be further discussed. The National Steel Company (CSN), for example, has been analyzed from both perspectives. See Telma de Barros Correia, "De vila operária a cidade-companhia: as aglomerações criadas por empresas no vocabulário especializado e vernacular", Revista Brasileira de Estudos Urbanos e Regionais, 4 (2001): 83-98; Adalberto Júnior Ferreira Paz, "Capital, trabalho e moradia em complexos habitacionais de empresa: Serra do Navio e o Amapá na década de 1950", in Do lado de cá, fragmentos de História do Amapá, coord.

Alexandre Amaral (Belém: Açaí, 2011), 461-468.

20 Leite Lopes, A Tecelagem dos Conflitos, 20. 
to certain types of socio-cultural organization. ${ }^{21}$ The village of Pau Grande is representative. Far from the rest of the city, surrounded by fences, with a single entrance protected by company guards, this neighborhood was "almost independent from the municipality". ${ }^{22}$

For their part, communist militants compared the working-class neighborhood to a sort of concentration camp. ${ }^{23}$ The communist newspaper Imprensa Popular described it as a "fiefdom set at the foot of the Magé mountains", exploiting workers in the factory and on the farm. ${ }^{24}$ In addition, in its coverage of an election for the local textile union, the paper stated that the workers would vote according to their sections in the factory; one of these was the "farm" section". ${ }^{25}$

The América Fabril company, in an ad in the Rio press, praised the infrastructure that surrounded its factories. Accompanied by a photograph of the workers' village in Pau Grande factory, the ad stressed that although they "had no city hall", the factories formed their own municipalities - a clear reference to the company's self-sufficiency. "We are a city. School, church, cobblestone streets, houses, gardens, hospital, pharmacy, dentist, and soccer field. Even agriculture and livestock”. ${ }^{26}$

This description, referring as it does to the idea of a "closed community", with features similar to those of a "total institution", was a deliberate attempt to emphasize the company's welfare initiatives rather than its control over workers' lives. However, examining the everyday lives of these textile workers reveals systematic acts of resistance against domination, both within and beyond the walls of the factory.

21 Space constraints do not allow us to offer a detailed study of each of the city's textile factories. Rather, we will avail ourselves of the many studies of these companies as needed to clarify issues raised here.

22 Renato Peixoto dos Santos, Magé: Terra do Dedo de Deus (Rio de Janeiro: IBGE, 1957), 170. The neighborhood was very different from Magé’s surrounding Inhomirim district, which was dominated by large, unproductive landholdings. holdovers from Brazil's imperial period (1822-1889). A line of the Leopoldina railroad crossed the district, a key factor in the its growth during Brazil's "land claim fever", which intensified in the 1950 s due to rapid population growth, industrialization, and the spatial expansion of urban areas.

23 Câmara Municipal de Magé, Livro de Atas Legislativas, 21 (Nov. 10, 1959 to Nov. 29, 1960), 1v-2.

24. Imprensa Popular (Mar. 4, 1953) 6.

25 Imprensa Popular (Jul. 21, 1954) 2. In another newspaper, the "Seção da Lavoura" "Agriculture Section"] was called "Escritório da Lavoura" ["Agriculture Office"]. See $O$ Globo (Jan. 13, 1958), 3.

26 O Globo (Nov. 6, 1964), 3. 
Even within the factory, there was space for certain indiscipline and a "workshop culture." Indeed, these might have seemed indispensable for proper production management. Besides, thanks to the autonomous exploitation of the resources offered by the company - such as the granting of workers' farms or plots for cultivation, the use of the forests around them for material purposes (firewood) or leisure (hunting, especially of birds) - these workers, usually of peasant origin, benefited from living conditions more favorable than we might assume if we were to consider only their factory jobs. There were even other things at their disposal, such as health care, religious associations, folk groups, housing (...), and the football club. ${ }^{27}$

In Magé, while the Pau Grande factory was managed by América Fabril from the $19^{\text {th }}$ century until the 1970 s, the other textile establishments changed hands repeatedly. However, after World War II, all the factories continued to be administered by the companies that had bought them during the Depression.

Santo Amaro was located in the municipality's most densely populated district. Although it did make some extra-industrial investments in its workforce, Santo Amaro's initiatives are insignificant compared to the other factories analyzed here. In 1952, after a serious crisis, it interrupted production and then sold its assets, in 1956. When it reopened, as Fábrica Itatiaia de Tecidos $\mathrm{S} / \mathrm{A}$, the company proposed an "immediate and complete renovation of the workers' houses" and to collaborate "materially in the urbanization of the land where it is located". ${ }^{8}$ Other Magé textile factories hired many of the workers who had lost their jobs due to the 1952 crisis. "(...) The two factories of Santo Aleixo kept more than 50\% of the employees from that factory", recalled a former worker. ${ }^{29}$

Under the administration of the companies that had purchased them in the 1930 s and 1940s, the factories in Santo Aleixo district (Andorinhas and Santo Aleixo) gradually helped foster new social dynamics. The result was the emergence of a specific textile culture, a product of both the centrality of industrial textile work and the everyday influence it exercised over workers' lives outside the factory. The pivotal moment came with the arrival of two businessmen who would exercise a profound influence over these factories. Hermann Mattheis and Othon Lynch Bezerra de Mello shaped the memories

27 José Sérgio Leite Lopes and Sylvain Maresca, “A Morte da 'Alegria do Povo”, Revista Brasileira de Ciências Sociais, 20 (1992): 121.

28 Santos, Magé: Terra do Dedo, 172.

29 Casimiro Virgínio da Rocha. Felipe Ribeiro, 1999, Guapimirim (Rio de Janeiro, Brazil). 
of a generation of workers, and both are frequently recalled as the creators of "a new factory and a new Santo Aleixo."

Inspired by American and European urban models, the new owners developed projects aimed not only at their companies but also at the surrounding community: they expanded and improved hydroelectric capacity to provide electricity and water, built workers' villages, schools, churches, streets, squares, medical centers, kindergartens, and movie theaters, and sponsored Carnival groups and football clubs. These transformations, particularly the new housing, had a significant influence on the lives of workers, Despite the employers' stated intentions to "civilize" and "modernize" the extra-industrial daily lives of their workers, in reality their initiatives constituted a sort of colonization or "front of advanced settlement". ${ }^{31}$ Broadly speaking, they were trying to reinforce aspects of "urban life" in the workers' villages, as if the factories were bringing the "city" to the "countryside". ${ }^{32}$

In 1935, the [Andorinhas $]$ factory had 70 workers' houses, most of which were roofed with zinc, without flooring or sanitation, and largely built with planks and wattle-and-daub. These houses, which did not meet the needs of the workers, were demolished and replaced with comfortable homes, with all the modern amenities, wallpapered, with flooring and electricity. Today the factory owns 200 houses, in addition to those under construction and being designed. Thanks to both the development of the company and the locality, Andorinhas has the following establishments, which did not exist in 1935: butcher, pharmacy, tailor, guest houses, restaurant, doctor, movie theater, two schools, one of which is maintained by the factory. Also underway is the construction of a daycare and a new school building with better facilities aimed at vocational education, all according to the law $(\ldots) \cdot)^{33}$

These two factories both exercised a pervasive influence over their workers and were located barely two kilometers apart. It would be tempting to conclude, based on these superficial similarities, that their villages had no significant differences between them. A more in-depth analysis, however,

30 Santos, Magé: Terra do Dedo, 162.

31 Sônia Maria Gonzaga de Oliveira, "Montanhas de Pano: fábrica e vila operária em Santo Aleixo" (Thesis, MN/UFRJ, 1992), 2.

32 Countryside here is understood as a "generic category referring to very different places of origin" that "in addition to the connotation of remote area, is also the place where people are poor and live in precarious conditions". See Rosilene Alvim, $A$ sedução da cidade: os operários-camponeses e a Fábrica dos Lundgren (Rio de Janeiro: Graphia, 1997), 21.

33 O Globo (Sep. 9, 1942), 6. 
reveals variations that shed light on the processes through which workers constructed their identities. For example, while the Bezerra de Mello group in Esther factory invested primarily in "family homes," the Mattheis' Andorinhas factory built houses specifically for single workers, which were commonly known as "little rooms." This reflected differences between the companies' hiring strategies in the post-war period, when jobs were abundant. ${ }^{34}$

\section{The "Golden Age" of the textile industry}

The arrival of new management in two important factories, along with the consolidation of América Fabril's position as a national leader in the textile industry, coincided with World War II. Together, these factors were decisive in the formation of the working class and the consolidation of an industrial culture. During the war, the city, its factories, and its workers experienced vast transformations through dense and far-reaching links to processes of national and global significance. For example, under the rule of Getúlio Vargas as elected president (1934-1937) and dictator (1937-1945), local textile unions were founded in 1935 and 1941, and the corporatist CLT (Consolidation of Labor Laws) was enacted in 1942. Simultaneously, factory owners and management became increasingly interested in addressing social issues through initiatives like workers' villages, even as they received tax

34 As previous studies have shown, factors specific to each factory decisively shaped the multiple identities constructed by workers. In addition to a shared social identity, as though both industrial communities (workers and employers) formed "one big, happy family," there was a strong rivalry between workers from both factories, which extended to their football clubs and carnival groups. Andorinhas employees were "from above," while those of Santo Aleixo were "from below." At the same time, the arbitrary behavior of factor owners, and, by extension, of the state, helped generate an identity based on a rivalry between workers and employers. This rivalry found expression though unions, or ties to political leaders or post-1945 parties. See Gonzaga Oliveira, "Montanhas de Pano”; Mello, Identidade, memória e história; Juçara da Silva Barbosa de Mello, "Fios da rede: industrial e trabalhadores na criação e expansão de um grupo empresarial (1920-1949)" (PhD Dissertation, Pontifícia Universidade Católica do Rio de Janeiro, 2012); Ribeiro, Memórias da Moscouzinho; Felipe Ribeiro, “A foice, o martelo e outras ferramentas de ação política: os trabalhadores rurais e têxteis de Magé/RJ (1956-1973)” (PhD Dissertation, Fundação Getúlio Vargas, 2015); Aline Fernandes Pereira, "A Fábrica Santo Aleixo: a importância de uma indústria têxtil como exemplo de trabalho manufatureiro livre em uma sociedade escravista" (Thesis, Universidade Severino Sombra, 2006); and Joana Lima Figueiredo, "Fábrica Santo Aleixo: Magé, Arte e Patrimônio da Industrialização (1847-1979)” (Thesis, Universidade Federal Fluminense, 2008). 
incentives to support the "war effort." Finally, the fall of Vargas's Estado Novo (New State) in 1945 was followed by the formation of new political parties, at precisely the moment when a significant portion of Brazilian workers were becoming voters for the first time, in a country where the right to work was predicated upon literacy.

The so-called "war effort" appeared amidst a strong patriotic and nationalist discourse, typical of this period of global conflicts, along with an authoritarian government, the key player in implementing labor legislation that it presented as its "gift" to workers. During the war, the progressive labor legislation which had just been "given" was partially suspended. The residents of Magé began to be treated as "production soldiers," with the motto, "Work in the factories, fight in the trenches". ${ }^{35}$ But the real beneficiaries of increased demand and suspended labor rights were industrial employers, including in the textile industry, who enjoyed quick profits due to an increase in demand, the suppression of recently-won labor rights, and the inclusion of textiles in a list of industries designated as having war-time "national interest". ${ }^{36}$

Workers benefited too, albeit more slowly, as many companies flush with cash renovated industrial buildings, installed new looms, and gradually took steps to shape the social lives of their workers outside the factories. ${ }^{37} \mathrm{By}$ adopting a powerful strategy of domination inside and outside the workplace, the management policies of these textile industries sought to reinforce corporatist ties between the workers, the companies, and, by extension, the authoritarian state that had ruled Brazil since 1937. ${ }^{38}$

35 O Globo (Sep. 9, 1942), 6.

36 The opportunism of the business community in Brazil during the war came up in a 1944 U.S. embassy memorandum: "It is evident that the Law of Mobilization [war effort] gives the textile industry autocratic control over its workforce and that this industry resorts to this control to respond to pressure that could come from the bottom up (...)". See Hélio da Costa, "Trabalhadores, sindicatos e suas lutas em São Paulo (1943-1953)", in Na luta por direitos: leituras recentes em História Social do Trabalho, coord. Alexandre Fortes; Antonio Luigi Negro and Fernando Teixeira da Silva (São Paulo: Unicamp, 1999), 94.

37 In the case of the Bezerra de Mello group, the "favorable war period" enabled the expansion of their business interests, with investments in the hotel industry, as they founded the Companhia Brasileira de Novos Hotéis, today known as Hotéis Othon, one of the largest chains of hotels in Brazil.

38 These corporatist bonds between workers, company and the state were addressed in a interesting analysis of the National Steel Company (CSN). See Elina Pessanha and Regina Morel, "Gerações operárias: rupturas e continuidades na experiência de metalúrgicos do Rio de Janeiro", Revista Brasileira de Ciências Sociais, 17 (1991): 74. 
The strategies of the textile entrepreneurs often aligned with the social policies of the Catholic Church, especially through its Workers' Circles, and politically with the centrist Social Democratic Party (PSD), founded by Vargas as he was forced from power in 1945. Expanding profits, increased investment in factory infrastructure and workers' daily lives, cooperation with the Church, and the emergence of more democratic institutional politics, along with the local factory administrations of Mattheis and Bezerra de Mello, helped legitimize the founding myth of a golden age.

The workers' villages of Santo Aleixo and Andorinhas factories differed from the village in Pau Grande factory. In the latter the factory was the "de facto local government", similar to the situation Leite Lopes observed in the city of Paulista, in Pernambuco. ${ }^{39}$ However, certain variables and differences Leite Lopes found in Paulista, including geographic isolation, a regional monopoly, and the creation of the new city with an independent local government (called "emancipação municipal" in Portuguese) were absent in Magé.

The social structure these companies organized from the 1940s onwards, through their factory-and-workers'-village system, combined with the consequent increase in jobs in construction and textile production, caused significant migration to the city, stimulated in part by newspaper ads: "Jobs for workers: the Colonization and Work Service has vacancies for bricklayers, carpenters, and workers in textile factories in the municipality of Magé". ${ }^{0}$ Employer-provided housing had an important role in recruitment, as it addressed the chronic housing insecurity that workers faced. ${ }^{41}$

In this context, there was a large influx of migrants to the city of Magé in search of jobs in the textile factories. These people and families came from Minas Gerais, Espírito Santo, Pernambuco, Bahia, Paraíba, Ceará, among others states, besides those that came from other countryside areas in the state of Rio de Janeiro. In some cases, the migrants already worked in other textile factories owned by the same company. However, previous studies have shown that the great majority came from rural areas, something also emphasized in the testimonies of many workers, who nearly always

39 Leite Lopes, A Tecelagem dos Conflitos, 192.

40 O Fluminense (July 27, 1945), 1.

${ }_{41}$ See Mike Savage, “Classe e história do trabalho”, in Culturas de classe: identidades $e$ diversidade na formação do operariado, coord. Cláudio Batalha; Teixeira da Silva and Fortes (Campinas: Unicamp, 2004), 25-48; and Mike Savage, "Espaço, redes e formação de classe”, Revista Mundos do Trabalho, 3 (2011): 6-33. 
remembered the countryside negatively. "Many people came from the countryside to these factories. So many people from the countryside... So many pretty girls... All illiterate...”. ${ }^{42}$

I came from Sana, a district in Casimiro de Abreu. I came here [to Santo Aleixo] when I was six or seven [in the 1940s]... The first person to live in the house belonging to the factory was my sister who got married. We arrived later. Me, my sister and my two brothers. (...) We came here because of the factory, because we could no longer work in the countryside, life in the countryside was very difficult. ${ }^{43}$

(...) We were happy [in the factory] because in the countryside we had to work more. We only ate what we planted and didn't earn any money. ${ }^{44}$

However, as Gonzaga Oliveira notes, "work in the textile factories does not always mean living in workers' villages. Thus many families live[d] on the hillsides surrounding the place or the existing farms - the current leaseholders." ${ }^{45}$ Indeed, factory housing was not easy to obtain. While many migrants found jobs as textile workers and received a house in the workers' village, others only got jobs and found housing in neighborhoods near their workplace; still others found neither jobs nor housing. Many migrants settled on the outskirts of district, near a colonial church (called Chapel of Santo Aleixo, as shown in figure 1) almost four kilometers from the nearest factory. "It was not possible for the employees to work here and live somewhere far away. Sometimes we lived in several places. We traveled one hour on foot to get to the factory", recalled a former foreman.46

Although they did not own the land, many migrant workers kept a private plot in their backyards, which they cultivated in their free time. For their part, migrants who could not find jobs in the factories settled in more remote areas, on land that belonged to others or was believed vacant, like the area around the chapel that gave the district its name. There they established farms of their own, where they grew staple crops for sale in the surrounding region. Some found work in textile factories later, but the category "weaver-

\footnotetext{
42 Lúcia de Souza, 2013. Interview for documentary film “Tear” (Loom), Taiane Linhares (Mar. 31, 2014).

43 Maria Oneida Peclat. Juçara Mello, Aug. 18, 2007, Magé.

44 Licério Ramos, 2013.

45 Gonzaga Oliveira, Montanhas de Pano, 35.

46 Anonymous interview given to Gonzaga Oliveira, Montanhas de Pano, 41.
} 
peasants”, as used by Giralda Seyferth, does not fit them, because it is not clear that they engaged in agricultural and factory work simultaneously. ${ }^{47}$

I came to Santo Aleixo in 1944 and lived a long time in the Capela neighborhood with my family. When we arrived, the Santo Aleixo chapel was surrounded by scrubland. If you looked from below [the church was built on a hill], you saw less than half of it. Then my father decided to clear the plot of weeds, because the church was abandoned. There was no feast held that year. The people went there to pray only on the day of the saint. It was only the following year that we began to have celebrate feast days every year. ${ }^{48}$

Although this land lay abandoned in the 1940s, the situation changed by 1956, when a road was built between the Santo Aleixo district and the Piabetá locality (road indicated with a red line on the map in Figure 1). Suddenly the old $19^{\text {th }}$-century plantations that covered the region were prime real estate. Speculation, the sale of overvalued land, ownership disputes, the forgery of deeds, squatting, and lengthy court battles ensued. As a result, América Fabril, owner of the Pau Grande factory, would begin a process of expansion along the new road. In addition to constructing a textile bleaching plant, the company sought to exert more direct control over agricultural production, as it constructed houses for some of its workers in the countryside. This constituted a strategy to protect the company's properties and secure its claim over surrounding areas, with the workers serving as a "human barrier" to demarcate the land they claimed. However, the factory's combination of industrial and agricultural production was far from a sign of "the crisis of the archaic Brazil and of its traditional labor relations". ${ }^{49}$ Rather, it was inextricably linked to notions of modernity; moreover, this combination of factories and farms was a flexible arrangement, one that the company could adjust according to the needs of the moment.

It is likely that this is the idea meant by entrepreneur Othon Lynch Bezerra de Mello when he stated that, "We must embark on the path to industrialization with love and enthusiasm.” Declarations like this one, along with the management practices he implemented in his factory, reveal a

47 "Worker-peasants" is a social category used in a study conducted in the textile city of Brusque, in the state of Santa Catarina, where workers who lived in rural areas owned cultivated land. Industrial wage labor tended to be supplementary and/or seasonal. Thus these workers were "farmers who worked at the factory," a very different experience from the situation in Magé. See Giralda Seyferth, “Aspectos da proletarização do campesinato no Vale do Itajaí (SC)", in Cultura छळ identidade operária, coord. Leite Lopes (1987): 103-120.

48 Maria Astézia de Oliveira Pereira. Felipe Ribeiro, July 1999, Magé.

49 Term used in the texts of Brandão Lopes, Crise no Brasil arcaico, 15. 
businessman fully in step with the trends of his time. ${ }^{50}$ As Eli Diniz has shown, the 1930s in Brazil were a time of "growing identification with the tenets that form the basis of industrial capitalism," in which the industrial bourgeoisie would have increased importance. ${ }^{51}$ Industrialization as a precondition for economic growth and national social development, a key principle of industrialist ideology, is central to the discourse of Bezerra de Mello, a man who would exercise a powerful influence on the formation of workers' identities in Magé and beyond.

We cannot forget that the export of our agricultural products can only get us so far. The big European countries (...) work hard to develop in their colonies the products they need to feed themselves and supply their industries. Countries whose wealth is based only on agriculture and livestock will someday regret it. (...) We don't suggest that Brazil abandon these two activities, but we insist that our politicians offer to industry the same protections they give agriculture and livestock. ${ }^{52}$

The war years transformed the Brazilian textile industry. Factory owners like Bezerra de Mello saw their wealth grow, due in part to the favorable business climate, but also to their own business strategies and opportunism. In 1939, Bezerra de Mello moved from Pernambuco to the city of Rio de Janeiro, where he set in motion plans to acquire three new factories. ${ }^{53}$ The structural changes envisioned by the Bezerra de Mello group would encounter in these three factories workers with their own well-established traditions of mobilization. For example, in the Santo Aleixo factory (now renamed Esther), workers already had a long history of struggle. However, the arrival of Bezerra de Mello, a few years after German entrepreneur Otto

50 Arguing in favor of "humane and progressive" capitalism, influential businessmen in the period, such as José Ermínio de Mores, president of Nitro Química of São Miguel Paulista, and A. J. Renner, a clothing industry leader in Porto Alegre, served, like Bezerra de Mello, as ideologues of modernization through industrialization.

51 Eli Diniz, "O Estado Novo: estrutura de poder, relações de classe”, in Historia geral da civilização brasileira. V. 10: O Brasil Republicano: sociedade e política (1930/1964), Ângela de Castro Gomes et al. (Rio de Janeiro: Bertrand Brasil, 2007), 97.

52 Othon Bezerra de Mello, “A evolução da indústria de tecidos de algodão em Pernambuco", Revista do Instituto Arqueológico, Histórico e Geográfico Pernambucano, 29 (1928-1929): 58.

53 These three factories, acquired between 1942 and 1943, were the Esther factory in Santo Aleixo, the Maria Amália factory in Minas Gerais, and the Carmen factory in Alagoas. All three factories underwent similar transformations under Bezerra de Mello management, and over the coming years their workers underwent experiences of consensus and resistance that reshaped social relations both within and beyond the workplace. 
Mattheis acquired the Andorinhas factory in 1935, set in motion a series of changes and new social dynamics that would help create a specific industrial culture and working class.

The Brazilian economy experienced profound changes in the 1930s. New trade and monetary policies coupled with restrictions on imports played an important role in the development of industry. ${ }^{54}$ At the same time, the country instituted far-reaching social legislation, which in turn resulted in a series of new measures on the part of industrial entrepreneurs. ${ }^{55}$ These measures, combined with the construction of roads, accelerated the development of the rural hinterlands of Magé, as families migrated from neighboring regions and other states, attracted by textile factories' offers of jobs, housing, health care, and leisure.

\section{Weaving Identities}

When the factories were located in rural areas with low population density, they were often converted into fronts of advanced settlement, since they attracted the population using the possibility of jobs and housing in the workers' villages. In these circumstances, the inhabitants, either workers who lived in the factory village or in neighboring regions, or small producers or merchants who settled around the factory, formed a population core which put down roots creating sociocultural situations that set them apart. [emphasis added]. ${ }^{56}$

The encounter between the rural and the urban, the agricultural and the industrial, repeated itself innumerable times in the daily lives of working families in factories far from Brazil's large cities. Thus, much like Leite Lopes found among factory employees in Pernambuco, who hailed from the semiarid backlands of the northeast of Brazil, wage labor in textile factories in Magé and its nearby areas was seen as an alternative, a supplemental source

54 Hildete Pereira Mello and Cláudio Monteiro Considera, "Industrialização Fluminense - 1930/1980”, Revista do Rio de Janeiro, 1 (1986): 113.

55 See Ângela de Castro Gomes, Cidadania e direitos do trabalho (Rio de Janeiro: Jorge Zahar, 2002). Gomes emphasizes that this labor legislation was not drawn on a blank slate. By the time Vargas came to power in the "Revolution of 1930," workers were already engaged in a systematic struggle for increased labor rights. The subsequent Vargas regime (1930-1945) paved the way for their formulation and implementation.

56 Gonzaga Oliveira, Montanhas de Pano, 2. 
of income during hard times. ${ }^{57}$ On the other hand, families for whom industrial work was the primary source of income might keep small farms and livestock to complement their factory wages; their extra-industrial activities were carried out on company-owned land with their bosses' tacit approval.

The farms were owned by the company and we could freely cultivate them; the company didn't complain. We could plant as much as we wanted there, you know? The land did not belong to us. I planted a lot of cassava ever since I was a child, with my father. I even made three sacks of flour with the cassava roots I planted, which I sold to people around here. My father had a capixaba. Capixaba is a way of saying he had a small farm (...) everybody lived like that (...) my father told me he operated two thread ironers in the factory to earn 3,500 cruzeiros a day working for 8 hours, but he always had his crops, I mean, he didn't buy flour, he always had a pig in the sty, chickens, he planted some corn as well $(. .$.$) everybody lived like that. { }^{58}$

These memories that positively link factory and farm work appear again and again among workers. Yet, reading between the lines, the above quote shows that under Bezerra de Mello's administration, the factory's large landholdings enabled it to exploit its workers more efficiently by inculcating a "morality of work" that extended its domination of employees beyond the workplace. Agricultural work was in fact extra work, outside the factory, a way for the industrialist to reduce his operating costs. Workers already subjected to overtime in the factory also had to produce their own food, something that should have been covered by their wages.

This overexploitation of surplus labor also applied to sugarcane workers in Pernambuco.

Many in the shop [also] cultivate a plot of land. Many plant workers get off at 4:30, poor things. When they leave at 4:30 their vision is already blurred. But that's how it goes, "I will make a sacrifice." Then they go home and the hatchet is already in the yard. They grab it and walk up the hill (this worker's land is on the hill set aside by the factory for workers' small farm plots). $[\ldots]$ They get there at 5:00. It's no longer time to work, right? They

57 Leite Lopes has observed that surpluses of rural migrants for industrial labor were linked to droughts and a corresponding decline in cotton and sugar production. See Leite Lopes, A Tecelagem dos Conflitos.

58 Paulo Lopes. Sônia Gonzaga Oliveira, Sep. 8, 1980, Magé. 
get there with huge effort, struggle. [By then] it's already night and at 6:00 they leave. ${ }^{59}$

The company gradually abandoned practices like conceding land for the cultivation of food. It was not by chance that this took place just as Vargas began implementing his new social and labor legislation, enshrining as rights things previously granted, in different forms and measures, as gifts by employers. As a worker named Elpídio put it, the company "put a guard in the forest," to keep people from cutting down even "a broomstick, even some beanstalks that grew very beautifully there near the boiler. When the man saw all that growing, he had it all cut down."60

We used to be able to do this. The company itself gave us plots, right? You asked for a plot to plant something, and they gave it to you. Back in the time of Mr. Serafin Clares, it was great; there were fields on all these hills around here. Today there isn't even a chayote vine. Othon did not give us that part of the property. He's dead now, but he didn't give it to us before and still doesn't.

Elpídio continues, "In the times of Othon, they gave us coffee with bread and butter" as a snack in the factory, and, "They gave us clothes once a year: each man got a suit and each lady, a dress. They took away everything”. The reason these benefits were suspended was a work stoppage demanding a Christmas bonus during which workers broke several machines. "We managed to get it. They gave us the Christmas bonus. The Christmas bonus came and they cut everything else".

Similarly, in the case of the Tecidos Paulista company, Leite Lopes sees the concession of land as another strategy for exploiting workers. Animal husbandry and food production complemented the insufficient salaries paid for exhausting factory work. "I had a small plot; otherwise my children would be in need”, Elpídio stated. It was simultaneously a wage supplement and a form of control, since if the company gave the land, it could also take it away. The eventual withdrawal of these gifts was a direct result of the success of workers' struggles to gain rights enshrined in law.

In Magés Pau Grande factory, the experience of Darcy Câmara was emblematic He spent only a short time as a weaver before becoming a head clerk, responsible for the bookkeeping of production per loom. Due to his

59 Anonymous interview with a sugar-mill worker in Pernambuco, identified as a locksmith. Leite Lopes, $O$ vapor do diabo: o trabalho dos operários do açúcar (Rio de Janeiro: Paz e Terra, 1978), 118.

60 Elpídio (retired foreman, born in 1897). Sonia Gonzaga Oliveira, Aug. 7, 1980, Magé. The following quotes come from this interview. 
"more enlightened" job, other workers frequently consulted him to ensure that their paychecks were correct. Whenever he realized that a salary or severance package was incorrect, Darcy would instruct the workers to file a complaint and enlist the union's support to ensure their employer complied with labor legislation. When the manager found out, Darcy was made to resign from his position as a bookkeeper and was sent to work in the fields, on land owned by the factory. In response, furious workers went on strike in solidarity with Darcy. ${ }^{61}$ For our purposes, the key insight this episode offers is the fact that a large textile company had workers both in the factory and in agriculture. So were workers in the Pau Grande textile workers or were they farmers? ${ }^{62}$

It is important to point out that labor legislation in Brazil, consolidated in the early 1940s, made it explicit that it was "inapplicable to rural workers", guaranteeing rights basically to industrial and commercial workers. This divergence in legal treatment distinguished Brazil from several countries in the Americas. An example is neighboring Argentina, where labor legislation has been extended simultaneously to rural, industrial and commercial workers, without distinction. However, we would like to stress that, in recent decades, research has highlighted the strong impact that Brazilian labor legislation has had on the rural world and on the peasants' imagination, thus encouraging, for instance, the search for some "legal loopholes" through Labor Court in lawsuits brought against bosses. This peculiarity in Brazil is another fundamental aspect in our research, aiming at a better understanding of the tensions between the rural and the urban. ${ }^{63}$

61 Workers wrote a poem about this episode in the traditional Northeastern cordel style.

62 In addition to the afore-cited work by Leite Lopes about the Companhia de Tecidos Paulista, which highlights the "overlap between centralized industrial and agricultural activities," studies have found similar overlaps in the Companhia Progresso Industrial do Brasil, better known as Fábrica de Tecidos Bangu, located in Rio de Janeiro; and the Fábrica Nacional de Motores (FNM), in Duque de Caxias, just outside Rio de Janeiro. See Márcio Piñon de Oliveira, Bangu: de fábrica-fazenda e cidade-fábrica a mais uma fábrica na cidade (Rio de Janeiro: thesis, Universidade Federal do Rio de Janeiro, 1991); and José Ricardo Ramalho, Estado Patrão e Luta Operária: o caso FNM (São Paulo: Paz e Terra, 1989).

63 See Marcus Dezemone, "Do cativeiro à reforma agrária: colonato, direitos e conflitos (1872-1987)" (PhD Dissertation, Universidade Federal Fluminense, 2008); Angelo Priori, "Legislação social e sindicalismo: um estudo sobre os trabalhadores rurais no norte do Paraná (1956-1963)" (Thesis, Universidade Estadual Paulista, 1994); and Clifford Andrew Welch, A semente foi plantada: as raízes paulistas do movimento sindical camponês no Brasil (1924-1964) (São Paulo: Expressão Popular, 2010). English version: The Seed Was Planted: The São Paulo 
Numerous studies have found industrial enterprises offering land, with similar motives, to workers' families, or even groups of factory workers - and not only in Brazil. Engels himself, in his work on workers' dwellings during early European industrialization, pointed out that, even with the introduction of machinery in the factories and intense proletarianization, workers did not give up their "vegetable garden and field". ${ }^{44}$ In his chapter on English textile workers, Thompson also pointed out the existence, in the early $19^{\text {th }}$ century, "of additional earnings from the cultivation of small tracts of land or vegetable gardens". ${ }^{65}$ In the $20^{\text {th }}$ century, in the face of wartime shortages, European industrialists encouraged their workers to cultivate subsistence crops. Significantly, this encouragement had a "pedagogical character," since agriculture might "keep the workers busy during their leisure time," thereby ensuring they would keep working, rather than following more bohemian pursuits. ${ }^{66}$ In Brazil, in addition to the Tecidos Paulista factory analyzed by Leite Lopes, there are other examples of industrial regions where the workers cultivated vegetable gardens. ${ }^{67}$

In Magé, workers' farms were not restricted to Pau Grande. Other studies of the Santo Aleixo workers have found that other sources of income especially from agriculture - always coexisted with factory work. The agricultural produce was consumed by the families or sold at a weekly Saturday-morning fair in front of the factory. These small plots, often combined with animal husbandry, not only complemented workers' wage labor, but were often survival strategies in the face of insufficient wages. ${ }^{68}$

Roots of Brazil's Rural Labor Movement, 1924-1964 (Pennsylvania: Penn State University Press, 1999).

${ }^{64}$ Frederick Engels, The Housing Question (New York: International Workers, N.D.).

65 Edward Palmer Thompson, A formação da classe operária inglesa: a maldição de Adão - v.2 (São Paulo: Paz e Terra, 2012), 147. English version: The Making of the English Working Class (London: Victor Gollancz Ltd., 1963).

66 Leite Lopes, A Tecelagem dos Conflitos, 94-95. The author cites the case of a French textile factory that maintained a "garden committee," responsible for encouraging workers to start vegetable gardens, a model copied by a similar textile factory in Camaragibe, Pernambuco, next to the Paulista factory.

67 The afore-cited works by Brandão Lopes on Minas Gerais, Leite Lopes on Pernambuco, and Fontes on São Paulo all note the existence of small farms maintained by workers. See Brandão Lopes, Sociedade industrial, 27-28; Brandão Lopes, Crise do Brasil arcaico, 28; Leite Lopes, O vapor do diabo, 118; and Fontes, Um Nordeste em São Paulo, 95.

68 Gonzaga Oliveira, Montanhas de Pano, 68. Astério dos Santos (head of the union in the 1950s and 1960s) also refers to this double work day. After his shift at the factory (from 5:00 a.m. to 1:00 p.m.), he began a new shift on the farm, until sunset. 
Despite local specificities, there were broad similarities in the ways workers were exploited by their employers, at work and in everyday life. As a result, workers collectively regarded themselves as a group forged by these experiences. They saw themselves as sharing common interests opposed to those of their employers. Consequently, it is necessary to distinguish these "workers on farms belonging to the factory," employed in agricultural production for the company, from "workers' farms," understood as work that complemented industrial wage labor. Although they all cultivated food crops, there was a difference between employment in the company's "crop division," and employees who grew crops during their free time, whether they were residents of workers' villages or were forced to live in surrounding areas. ${ }^{69}$

Workers on factory-owned farms were mainly sharecroppers who owed onethird to one-half their production to the company. These products were sold in the factory store, which might be owned by the company itself or contracted to a third party. The remainder was for the domestic consumption of the producer, who was forbidden to sell it to third parties. In practice, this restriction was not always obeyed.

My father would leave at 3:00 a.m. in secret, with his donkeys, to sell somewhere else, because he could sell at higher prices than [he could] here. [...] If [the factory] found out he was selling, he would be punished. So he went out in the early morning to sell outside, in Piabetá or Imbariê, because he made more money there. Otherwise he would be a slave of the factory all the time. ${ }^{70}$

\section{Conclusions}

In this brief overview, we analyzed the relationship between textile factories and workers in the city of Magé (Rio de Janeiro, Brazil), taking into account the specific characteristics of each factory and their interactions. In each factory, there was a marked tension between rural and urban life, above all after the mass migration that began during and after World War II. Workers

69 This differentiation helps better us understand the case of the transfer of the clerk Darcy Câmara from the factory to the company farm. Similarly, Marco Antonio Teixeira's interviews with former residents of the region near the América Fabril company suggest that those who worked on the factory-owned farms were not employed in textile labor, and vice-versa. Of course, it was still possible to combine factory and farm work, the latter taking place after factory work hours. See Marco Antônio dos Santos Teixeira, "Conflitos por terra em diferentes configurações: um estudo de caso em Magé, RJ” (Thesis, Universidade Federal Rural do Rio de Janeiro, 2011), 44.

70 Geremias and Márcio. Leonilde Medeiros, July 2001, Magé. 
shared a common identity related to their origin as rural migrants who worked the land and brought with them many patriarchal peasant values, which were in constant tension with the hierarchical daily life of the factory and its surrounding area, the workers' village.

Likewise, several factory administrations have relied on patriarchal devices, to a greater or lesser extent, to control their textile workers. The so-called industrial paternalism which to some extent was opposed to the challenge of Brazilian industrialists verified by Stein, to implement "modern management methods" 71 . Among the textile factories analyzed in this article, there were administrations that maintained extensive agricultural land under their administration and quite integrated with their textile worker's village, with restriction rules that prohibited the sale of products from their plantations, which in turn was constantly denounced as landowning exploitation by textile unions. Other administrations encouraged the creation of a home garden in the backyard of workers' homes as another form of control, either for occupying the free time of their workers, or for a possible complementation of food or income, which minimized social instabilities in the company. There was also the agency of the workers themselves who sought to organize their small land, regardless of the incentives of local manufacturing organizations. So, for all that we have listed throughout the article, we reinforce how the term "factory worker's farm" (roçado operário) is insufficient to characterize or define such distinct and complex experiences.

Thus, as we have shown here, the term "factory worker's farm" could encompass many unique arrangements, including (i) workers' farms stimulated by the factory; (ii) workers' farms voluntarily cultivated; (iii) workers on factory-owned farms, and (iv) farms of migrants who did not work in the factory.

Focusing on the factory workers' village system, we have shown that these companies exercised social domination in various ways, as they reinforced internal divisions among the region's workers. On the other hand, in spite of exercising a strong, and not always positive, influence upon the lives of their workers beyond the factory walls, the benefits the factories offered as "gifts" became a symbol of safety, tranquility, and comfort in the collective imagination of textile workers, meeting as they did a central structural concern of the working classes: housing. This is clear both in the oral

71 Antonio Luigi Negro, "Paternalismo, populismo e história social”, Cadernos AEL, 11 (2004): 13-37. 
testimonies of workers from Magé and in studies of other parts of Brazil (and the world) and other industries. As José Ricardo Ramalho puts it:

(...) The possibility of living in the villages appears in many of the testimonies of workers and employees as something extremely positive, associated with other 'benefits' offered by the factory to keep under control a group of workers essential to its functioning. The general deprivation in the lives of workers, the need of employment and family wellbeing, seemed to be stronger arguments than the obvious limitations imposed on those who lived in the villages. ${ }^{72}$

Therefore, by proposing throughout this article new possibilities and typologies for understanding the various forms these "workers' farms" could take, we hope to contribute to broader debates in labor history about the relationship between rural and urban work, especially in Latin America and the Global South. 
Título: Trabajadores que producen tejidos industriales y cultivan la tierra: trabajo textil, migraciones y conexiones entre trabajo rural y fabril

Resumen: Este artículo explora las experiencias de los trabajadores migrantes, muchos de zonas rurales, que se establecieron en un importante centro de la industria textil en Brasil, ubicado en el estado de Río de Janeiro. Al articular varias fuentes históricas, buscamos comprender tanto las prácticas agrícolas mantenidas por los migrantes debido a su origen como los incentivos para trabajar en los campos fomentados por los empleadores fabriles. En contraste con los estudios guiados por nociones de modernización que han vinculado crudamente al mundo manufacturero con el progreso en oposición con el agrícola, este artículo examina cómo los trabajos rurales y fabriles coexistieron en múltiples combinaciones. Sostenemos que el término "roçado operário", utilizado en muchos estudios, no es suficiente para describir un fenómeno social tan variado y complejo. Por lo tanto, proponemos nuevas reflexiones para comprender las diversas formas de uso de la tierra por estos trabajadores.

Palabras clave: trabajadores textiles, migración, trabajo rural y fabril, identidades de tejedores.

Título: Trabalhadores que produzem tecidos industriais e cultivam a terra: trabalho têxtil, migrações e conexões entre trabalho rural e fabril

Resumo: Este artigo explora as experiências de trabalhadores migrantes, muitos deles procedentes do meio rural, que se estabeleceram em um importante pólo da indústria têxtil do Brasil, localizado no estado do Rio de Janeiro. Articulando diversas fontes históricas, buscamos compreender tanto as práticas agrícolas mantidas pelos migrantes devido à sua origem, quanto os incentivos ao trabalho na lavoura promovidos pelos empregadores nas fábricas. Em contraste com estudos guiados por noções de modernização que vincularam grosseiramente o mundo fabril ao progresso em oposição ao agrícola, este artigo examina como o trabalho rural e o trabalho fabril coexistiram em múltiplas combinações. Argumentamos que o termo "roçado operário", utilizado em muitos estudos, não é suficiente para descrever um fenômeno social muito mais variado e complexo. Portanto, propomos um novo arcabouço para a compreensão das diversas formas de uso do solo por esses trabalhadores.

Palavras-chave: trabalhadores têxteis, migração, trabalho rural e fabril, identidades de tecelões. 